\title{
The State of Working New Hampshire 2006
}

\author{
A L L IS ON CHURILLA
}

$\mathrm{N}$ ew Hampshire's recent history has been one of economic strength. For years, the state has maintained a high national ranking on median personal, family, and household income and a low national ranking on persons living in poverty. ${ }^{1}$ Analyses in this report suggest that New Hampshire continues to fare well economically, both in relation to the nation as a whole and in relation to other states in New England. Labor force participation is high, job growth is positive, and workers' wages are on the rise.

But recent developments point to growing disparities in the state. Young workers appear to be losing ground in the paid labor force, jobs in manufacturing and select serviceproviding industries continue to decline, and wage inequality is on the rise. These trends suggest New Hampshire needs to explore strategies to strengthen the education and training of workers with lower education and fewer skills, and to address the needs of young workers in the state. In the summer of 2006, the Annie Casey Foundation released its Kids Count reports on child well-being across the country. The state experienced a rise in both child poverty and in the number of families without a full-time worker. ${ }^{2}$ Other studies indicate that income inequality is growing in the state. ${ }^{3}$ These findings are consistent with the trends reported below, and show that low and moderate income families in New Hampshire may face growing challenges in the globalizing economy.

This brief highlights these and other trends related to the economic and workforce characteristics of New Hampshire's workers. It is produced in cooperation-and its release coincides-with the Economic Policy Institute's (EPI) national report, The State of Working America 2005/2006. ${ }^{4}$

\section{Labor Force Participation is High, but New Hampshire's Youngest Workers See a Decline Overall, New Hampshire had a 71 percent labor force participation rate in 2005. Labor force participation in the state compares favorably with the national average and other states in the region. In 2005, the state's labor force participa- tion rate was higher than both the national participation rate (66 percent) and the rate of any other New England state.}

Next to Vermont, the state also had the lowest unemployment rates and underemployment rates in the region. ${ }^{5}$

New Hampshire's workforce participation rates have been declining since 2000, when participation stood at 73 percent. The overall decline in workforce participation was largely caused by the decline in young adults' labor force participation over this time period. Between 2000 and 2005, there was a decline in the percentage of 16 to 24 year olds participating in the labor force (from 75 percent to 67 percent). This could be related to enrollment at institutions of higher education. But there were also increases in unemployment (from 7 percent to 9 percent) and underemployment (from 12 percent to 16 percent) for this age cohort between 2000 and 2005.

\section{Positive Job Growth, But Losses in Certain Sectors}

Between 2000 and 2005, New Hampshire's nonfarm employment grew by approximately 13,000 jobs, a 2 percent increase. $^{6}$ The increase mirrored job growth in Vermont and exceeded job growth in the other New England states over the same period (with the exception of Rhode Island at 3 percent). New Hampshire's employment growth also outpaced national growth over the same five-year time period.

Most recently, job growth in the state trailed national figures. Between 2004 and 2005, job growth in the state was slightly below the national average (1.2 percent in New Hampshire compared to 1.5 percent nationally). National job growth exceeded job growth in all six New England states over this time period.

Job growth was uneven across New Hampshire's counties. While data is not yet available for all four quarters of 2005, Table 1 shows that the greatest job growth between 2000 and 2004 occurred in Carroll County. Next to Grafton County, this county also had the second greatest growth in wages over these four years. Four counties experienced a loss of jobs; two of these counties also had wage growth that was below the state figure of 12 percent.

Between 2000 and 2005, the most significant job growth in the state occurred in construction (employment up 19 percent), education and health services (up 17 percent), and 
Table 1. Growth in Average Monthly Private Sector Employment and Average Weekly Wages in New Hampshire Counties, 2000-2004 (in 2004 Dollars)

\begin{tabular}{lcc}
\hline & $\begin{array}{c}\text { Growth in Employment } \\
(2000-2004)\end{array}$ & $\begin{array}{c}\text { Growth in Wages } \\
(2000-2004)\end{array}$ \\
\hline Carroll County & $5.7 \%$ & $18.8 \%$ \\
Grafton County & $3.8 \%$ & $25.0 \%$ \\
Rockingham County & $2.6 \%$ & $11.9 \%$ \\
Merrimack County & $2.3 \%$ & $10.4 \%$ \\
Belknap County & $2.1 \%$ & $14.5 \%$ \\
Cheshire County & $1.6 \%$ & $14.1 \%$ \\
Hillsborough County & $-1.3 \%$ & $11.0 \%$ \\
Coos County & $-1.7 \%$ & $12.4 \%$ \\
Strafford County & $-2.0 \%$ & $6.7 \%$ \\
Sullivan County & $-6.3 \%$ & $13.6 \%$ \\
\hline
\end{tabular}

Source: New Hampshire Department of Employment Security Economic Statistics

financial activities (up 15 percent). Over the five-year time period, these three industries added approximately 23,600 jobs to the state economy. Growth in five other industries added another 17,900 jobs between 2000 and 2005, for a total gain of approximately 41,500 jobs in the state.

In contrast, over the same five-year period, a substantial number of jobs were lost in manufacturing, transportation and utilities, information, and other services. These losses contributed to the decline of 28,000 New Hampshire jobs between 2000 and 2005. This was not unique to New Hampshire; all New England states experienced considerable drops in manufacturing and information jobs over this time period. At the national level, employment in manufacturing declined 18 percent and information dropped by 16 percent.

\section{Steady Growth in Workers' Wages Confounded by Increases in Inequality}

New Hampshire workers' median hourly wage was $\$ 15.93$ in 2005. This was higher than the national figure $(\$ 14.28){ }^{7}$ It represents 7 percent growth in the median wage since 2000, outpacing growth in all other New England states over the same time period. New Hampshire median wages have trailed New England's since 1979. In 2005, however, the state median wage surpassed the regional figure.

There has been a general pattern of growth in the median wage over the past two decades, with some losses in the early and mid-1990s. By and large, median wages in the state have remained above their 1979 level, with the exception of about four years in the early 1980s. Furthermore, while wage growth slowed in the nation in the late 1990s, wage growth in New England and in New Hampshire continued its steady ascent through 2003.
Figure 1. Percent Change in Employment by Industry in New Hampshire, 2000-2005

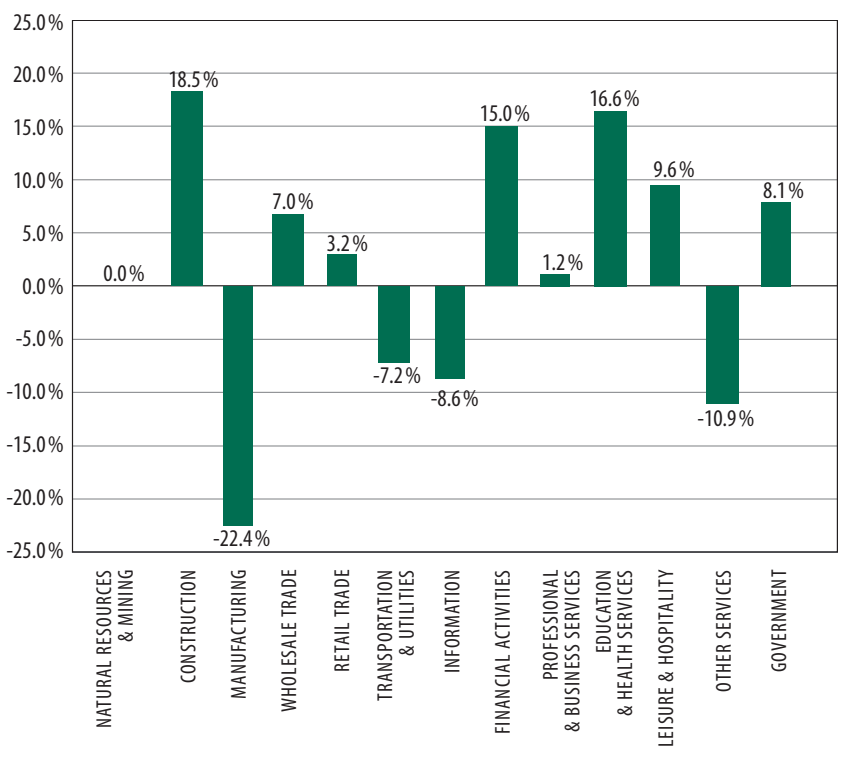

Source: Economic Policy Institute analysis of Current Employment Statistics data

Figure 2. Median Wages in New Hampshire, New England, and the United States, 1979-2005 (in 2005 Dollars)

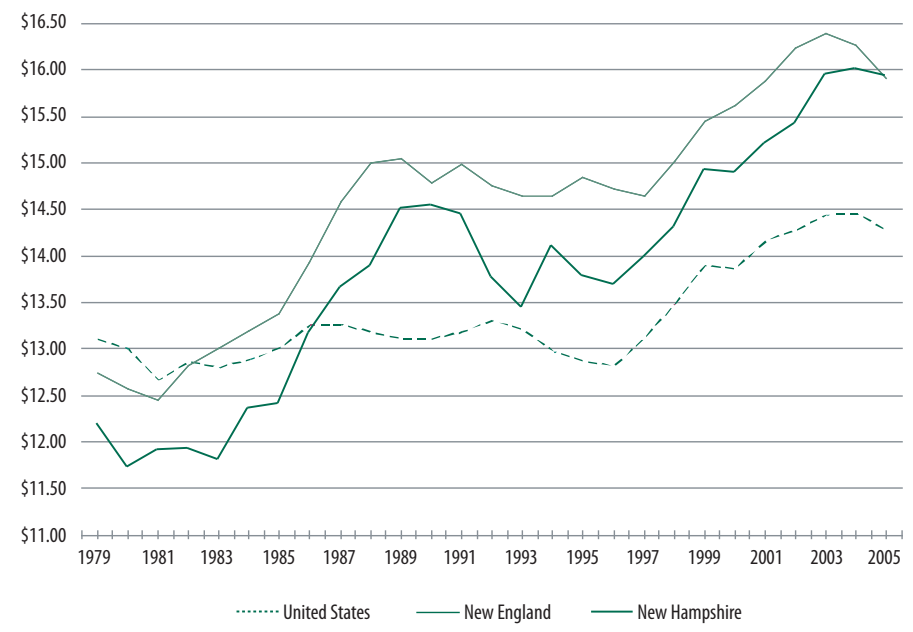

Source: Economic Policy Institute analysis of Current Population Survey data

But median wages conceal inequalities in wage growth for workers across the earnings spectrum. High wage workers have experienced the most substantial growth in wages since 1979 , with wages increasing 43 percent for these workers. ${ }^{8}$ In comparison, low wage workers have experienced only 21 percent growth in their wages over the same time period. 
Figure 3. Growth in Hourly Wages in New Hampshire, 1979-2005 (in 2005 Dollars), Relative to $1979=100$

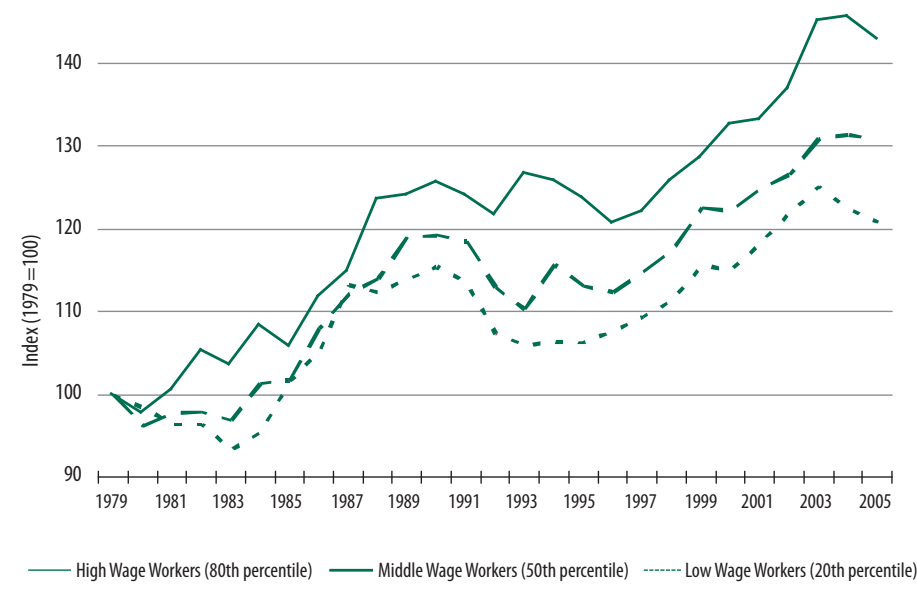

Source: Economic Policy Institute analysis of Current Population Survey data
In 2005, 16 percent of workers in New Hampshire earned a wage that fell below the poverty level. ${ }^{9}$ This reflects a slight increase in recent years from 15 percent in 2003. Nonetheless, the state maintains the lowest percentage of povertylevel workers among all New England states and falls well below the national figure of 24 percent.

\section{New Hampshire Labor Force Is Well Educated}

New Hampshire maintains a well-educated labor force. In 2005, over one-third of the workforce had a four-year college degree and well over 60 percent had at least some college education. In New England, only Massachusetts and Connecticut have greater percentages of college-educated workers (40 percent and 36 percent, respectively). Compared to the national figure, there is a greater prevalence of fouryear college graduates in the labor force in all New England states. Twenty-nine percent of the national labor force has a college degree.

This reflects a twenty-year trend of increasing educational attainment among the state's workforce. Since 1986, a growing share of the workforce has held four-year college degrees. Over the same period, the share of the labor force with a high school degree or less decreased.

Figure 4. Education of New Hampshire's Workforce, 1979-2005

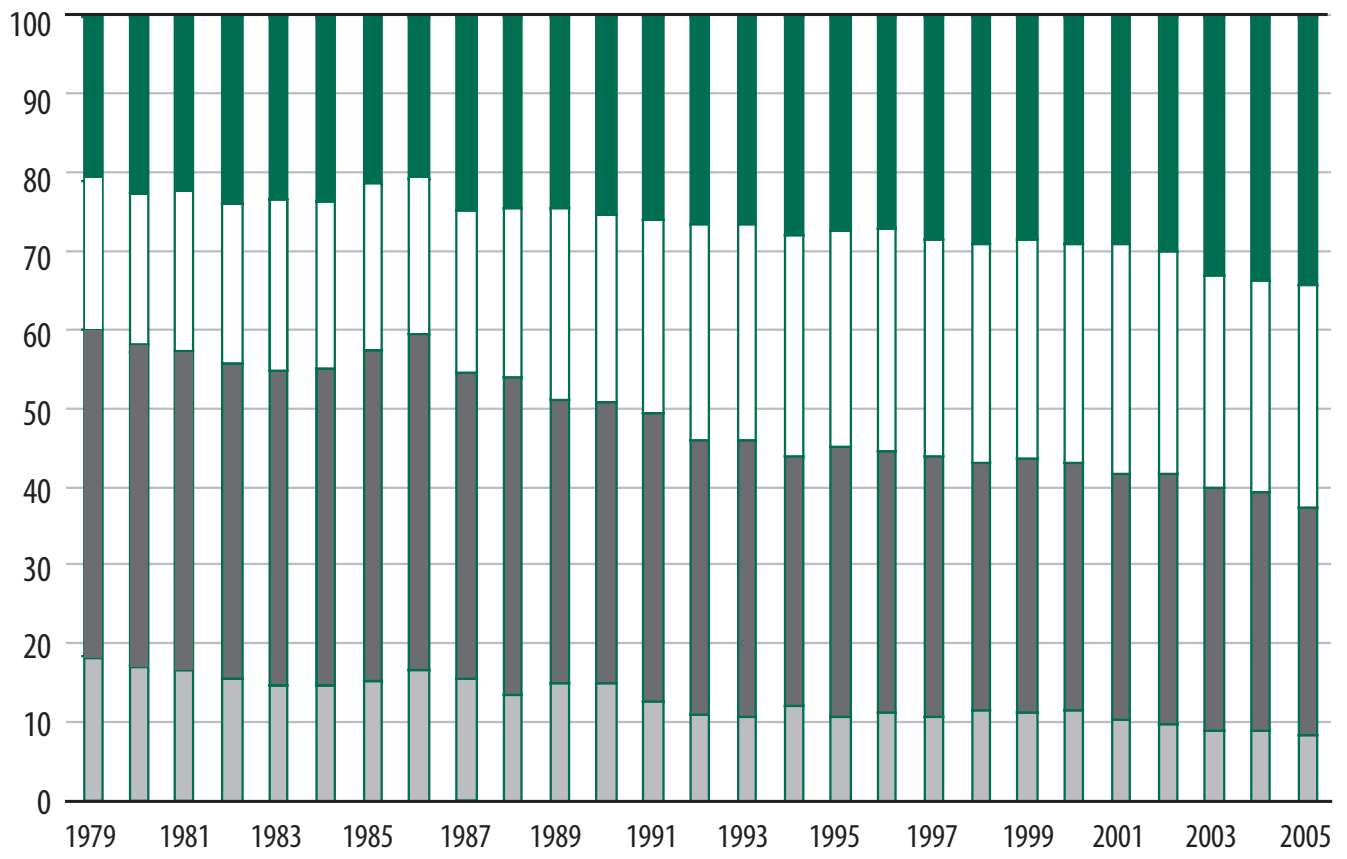

Less than high school

High school degree

Some college

Four-year college degree or higher 


\section{Increasing Rewards for Workers with Higher Education}

There has been a corresponding increase in median wages for college-educated workers. Figure 5 shows that collegeeducated workers' wages have increased 48 percent since 1979.

Workers with less than a college degree have seen less growth in their wages, ranging from 18 percent for workers with some college education to 20 percent for workers with a high school degree. Wage growth patterns for these two groups of workers have remained similar since the early 1990s.

\section{Female Wages Trend Steadily Upward}

Compared to the other five New England states, New Hampshire performs relatively well on measures of gender equity. Second only to Vermont, the state had a high female labor force participation rate (65 percent) and a low female unemployment rate (4 percent) in 2005. Thirty-five percent of female workers worked part-time, the lowest percentage of any New England state but higher than the national figure of 30 percent.

Among male workers, the state had the highest male labor force participation rate (78 percent) and the lowest male unemployment rate ( 4 percent) in the region. About one in six male workers were employed part-time, again the lowest in New England and equal to the national figure.

Women workers in New Hampshire benefited from the highest growth rate in median wages in the New England region (15 percent). Growth in women's median wages in the state has been positive over the last two decades, outpacing men's wage growth (see Figure 6). Yet female workers still earned about $80 \$$ for every dollar earned by men in New Hampshire. In New England, only Connecticut had a lower female-to-male earnings ratio (76 percent).

\section{Conclusion}

On the whole, New Hampshire's history of economic prosperity and growth continues today. Labor force participation remains high relative to the national average and other New England states, while the state maintains moderate positive growth in jobs and wages. New Hampshire's labor force is increasingly well-educated and the state's working women continue to make positive gains. This can all be interpreted as good news for workers and their families in the Granite State.

But other specific trends that are emerging in the state may be worrisome to New Hampshire policymakers. Declines in labor force participation among the state's youngest workers and growing wage inequality, particularly across levels of educational attainment, suggest that many workers'
Figure 5. Growth in Hourly Wages by Education in New Hampshire, 1979-2005 (in 2005 Dollars), Relative to 1979=100

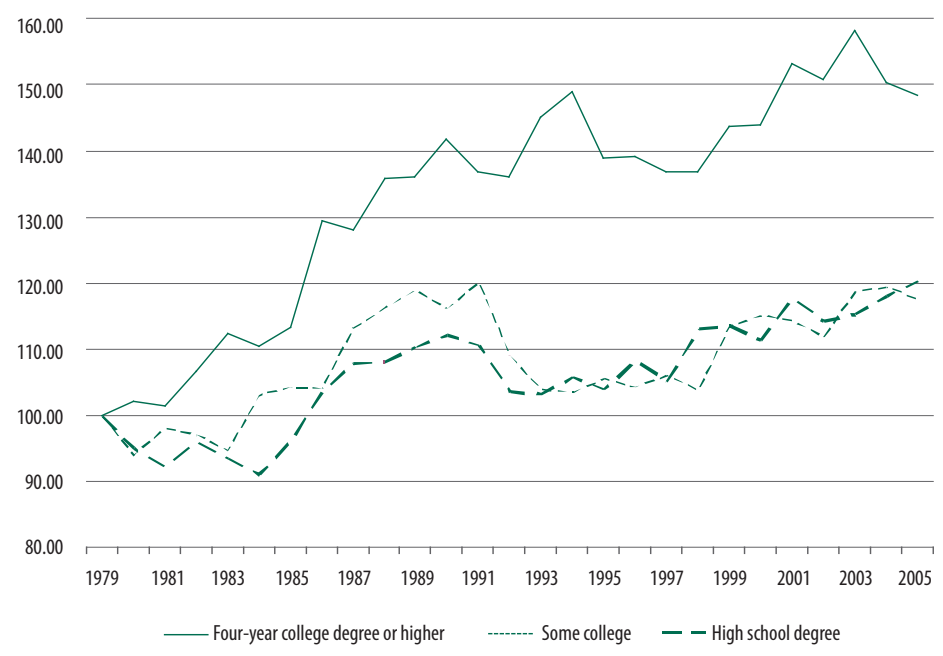

Source: Economic Policy Institute analysis of Current Population Survey data

economic well-being will increasingly depend on their workforce preparation. The state has an interest in maintaining its highly educated workforce to enhance the economic and social well-being of workers, families, and the state.

New Hampshire also has an interest in facilitating opportunity for workers interested in advanced training and education. It is therefore troubling that the cost of higher education in New Hampshire is among the highest in the nation. ${ }^{10}$ Development of the workforce will require investments in training and higher education. In particular, policy should be attentive to high costs associated with enrolling in educational programs and enhancing accessibility of higher education to workers in the state.

Trends through 2005 suggest that, by and large, New Hampshire has seen continued progress for workers in the state. This good news must be balanced by concern about recent developments in wage inequality and labor force participation in the state. Effective policy measures could address workforce development before the state experiences continued income inequality. Taking recent trends as forewarnings, policymakers may use this time to $\mathrm{New}$ Hampshire's benefit to guard against further cleavages in the labor market and workers' wages. 
Figure 6. Male and Female Wages in New Hampshire, 1979-2005

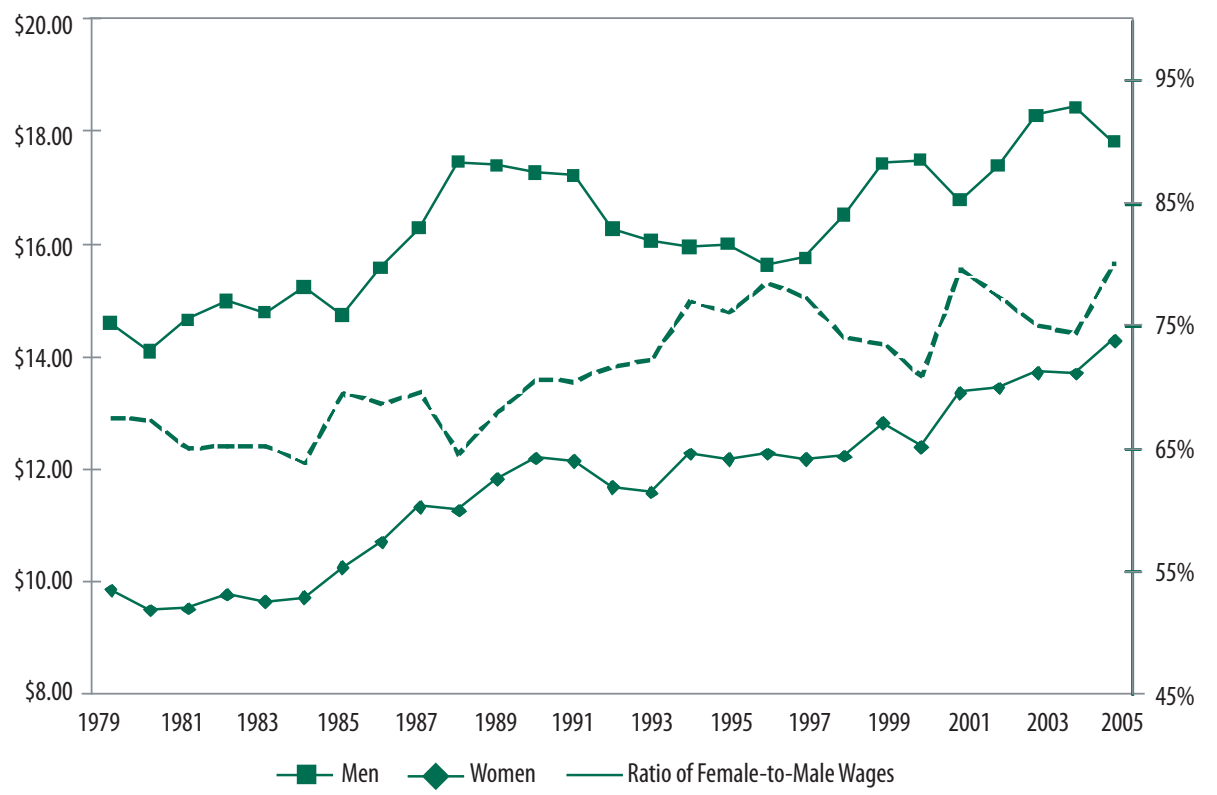

Source: Economic Policy Institute analysis of Current Population Survey data

\section{Interpreting the Female-to-Male Earnings Ratio}

The female-to-male earnings ratio is a measure that is commonly used to gauge the earnings gap between female and male workers. The ratio is computed by dividing the female median wage by the male median wage. It is commonly interpreted as the amount of money women earn for every dollar earned by men. For example, a female-to-male earnings ratio of 0.80 means that, on average, working women earn $80 \zeta$ for every dollar earned by working men.

There is greater equity in women's and men's median wages as the earnings ratio gets closer to $\$ 1.00$. In other words, women appear to be better off in states with a higher earnings ratio because there is less inequality in wages.

But the earnings ratio should be interpreted with caution because it is also a measure of the strength of male wages. The earnings ratio tends to increase during periods when male wages decline, even without an increase in female wages. Thus, women appear to fare better even without an increase in their average wages. Similarly, women appear to fare worse in states or during periods when male wages are strong, even though women's average wages may be quite high. The conclusion is that a narrowing gap between female and male wages is good news only if it reflects growth in female wages without an accompanying drop in male wages.

\section{A U T H OR}

Allison Churilla is a Policy Fellow at the Carsey Institute (allison.churilla@unh.edu).

\section{A C K N O W L E D G E M E N T S}

The author would like to thank Cynthia Duncan, Kristin Smith, Ross Gittell, and Reagan Baughman for their thoughtful comments on earlier versions of this issue brief. Financial support was provided by the Jane's Trust and the New Hampshire Charitable Foundation. Responsibility for the analysis lies with the Carsey Institute. 


\section{$\triangle$ UNIVERSITY \\ of NEW HAMPSHIRE}

\section{CARSEY}

Building knowledge for families and communities

in the 21st Century.

The Carsey Institute at the University of New Hampshire conducts independent, interdisciplinary research and communicates its findings to policymakers, practitioners and the general public.

Huddleston Hall

73 Main Street

Durham, NH 03824

(603) 862-2821

www.carseyinstitute.unh.edu

This brief is part of a series of Carsey Institute Reports on

Changes in New England.

\section{Endnotes}

${ }^{1}$ Economic and Labor Market Information Bureau. 2006. Vital Signs 2006: Economic and Social Indicators for New Hampshire, 2001-2004. Concord, NH: Economic and Labor Market Information Bureau of the New Hampshire Employment Security.

${ }^{2}$ Annie E. Casey Foundation. 2006. The Annie E. Casey Foundation 2006 Kids Count Data Book. Baltimore, MD: Annie E. Casey Foundation.

${ }^{3}$ Economic Policy Institute/Center on Budget and Policy Priorities. 2006. Pulling Apart: A State-by-State Analysis of Income Trends. Washington, DC: Economic Policy Institute and the Center on Budget and Policy Priorities; Seif, Amy. 2006. "Income Inequality in New England: An Interview with Ross Gittell and Jason Rudokas." Retrieved September 6, 2006, from University of New Hampshire Carsey Institute Web Site: http:// www.carseyinstitute.unh.edu/ gittell_interview.html

${ }^{4}$ Unless otherwise noted, all figures are drawn from EPI's analysis of Current Employment Statistics and Current Population Survey data. The Current Employment Statistics program surveys a sample of over 400,000 business establishments and government agencies to provide industry estimates of job growth, hours, and wages. Data is collected as part of a joint effort between state employment security agencies and the Bureau of Labor Statistics. The Current Population Survey program surveys a nationally representative sample of approximately 50,000 households (and individuals in those households) to provide demographic and employment information on the United States population. The survey is conducted by the U.S. Bureau of the Census for the Bureau of Labor Statistics. Except when noted otherwise, dollar amounts were adjusted for inflation to 2005 dollars.
${ }^{5}$ Unemployed workers include those willing and able to work that looked for work in the four weeks preceding data collection. Underemployed workers include those working part-time that desire full-time employment, "discouraged" workers that have given up seeking employment, and "marginally attached" workers that are not currently searching but desire employment and have looked for work in the previous 12 months.

${ }^{6}$ Employment figures reflect full-time and part-time employees in nonfarming industries in the state.

${ }^{7}$ The median hourly wage is the wage earned by the worker at the exact middle of the wage distribution. In other words, half of the state's workers earn more than this wage and half earn less.

${ }^{8}$ In this report, low, middle, and high wage workers are defined by their placement on the wage spectrum. Low wage workers' earnings place them in the $20^{\text {th }}$ percentile; in other words, $20 \%$ of workers in the state earn less than this wage. Middle wage workers earn wages at the $50^{\text {th }}$ percentile (or the median) and high wage workers earn wages at the $80^{\text {th }}$ percentile.

${ }^{9}$ Poverty wage was $\$ 9.60 /$ hour in 2005 Consumer Price Index research series using current methods (CPI-U-RS) adjusted dollars.

${ }^{10}$ Bravo, Noel and Minh Ta. 2006. "Policy Matters State Policy Brief-January 2006: New Hampshire." Center for the Study of Social Policy: Washington, DC. 